\title{
The inhibition of methicillin-resistant Staphylococcus aureus by essential oils isolated from leaves and fruits of Schinus areira depending on their chemical compositions*
}

\author{
Liliana S. Celaya', Marta H. Alabrudzińska², Ana C. Molina1', Carmen I. Viturro1,\# \\ and Silvia Moreno ${ }^{3, \# \rrbracket}$
}

1PRONOA Laboratory, F.I., National University of Jujuy, Jujuy, Argentina; 2Intercollegiate Faculty of Biotechnology, University of Gdańsk and

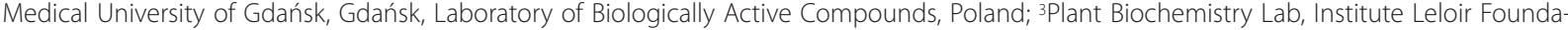
tion, IIBBA-CONICET. Argentina

\begin{abstract}
Schinus areira $L$. is a native plant from South America used for centuries in traditional medicine. Here, we investigate the antimicrobial activity of four essential oils extracted from leaves and fruits of S. areira exhibiting different chemical profiles. The antibacterial activity against the human pathogenic bacteria Staphylococcus aureus susceptible as well as methicillin resistant strain was assessed by the broth microdilution assay. The results showed that the limonene-rich oil extracted from the leaves and fruits have potent antibacterial effect on S. aureus ATCC 25923, while the a-phellandrene-rich fruit oil having a lower content of limonene showed the lowest antibacterial efficacy. In this work, for the first time, we demonstrated the bactericidal activity of essential oils isolated from fruits and leaves of $S$. areira against susceptible and methicillin resistant $S$. aureus strains. All results point out the potential use of the $S$. areira oils as antimicrobial agents to be used, at least against Staphylococcal infections.
\end{abstract}

Key words: Schinus areira; essential oils; antibacterial; Methicillinresistant Staphylococcus aureus

Received: 18 October, 2013; revised: 23 January, 2014; accepted: 25 February, 2014; available on-line: 18 March, 2014

\section{INTRODUCTION}

Plant-based essential oils (EO) are well known to exhibit a wide range of biological activities as well as they tend to have low mammalian toxicity, less environmental effects and wide public acceptance (Dorman \& Deans, 2000). The use of plant compounds as antimicrobial agents is enjoying great popularity in the late 1990s (Cowan, 1999). Since the middle ages, the EO has been widely used in pharmaceutical, sanitary, cosmetic, and agricultural and food industries (Bakkali et al., 2008). A recent overview study indicates that $\mathrm{EO}$ can be used as effective antiseptics against many species, including multidrug-resistant bacteria, such as methicillin-resistant Staphylococcus aureus (MRSA) (Kon \& Rai, 2012). These $S$. aureus strains resistant to numerous antibiotics as methicillin, penicillin as well as quinolones and aminoglycosides are a worldwide problem increasing the probability of unfavorable infection outcome (Grundmann et al., 2006; Chen et al., 2010). Therefore, one of the proposed methods to cope with MDR bacteria is the use of natu- ral antimicrobial substances such as the plant EO (Langeveld et al., 2014).

Molle, aguaribay, pepper tree (USA.), among others, refer to two species of Schinus (Anarcadiaceae family) closely taxonomically related as $S$. molle $\mathrm{L}$. and $S$. areira L. native from South America (Muñoz, 2000). The essential oil of these aromatic plants is obtained by distillation and contains a variety of volatile molecules such as terpenes and terpenoids, derivatives of phenol compounds and other aromatic and aliphatic components. The fruits and leaves of these plants are used in traditional medicine as antibacterial, antifungal and antirheumatic, anti-conjunctivitis, tuberculosis, bronchitis, cough (Molina-Salinas et al., 2007).

Schinus areira L. [synonymous: Schinus molle L. var. areira (L.) DC.] is distributed principally in Perú, Bolivia, Northern Chile. It grows naturally in Argentina, from 0 to $3000 \mathrm{~m}$ altitude, in central and northwest of the country (Catamarca, San Luis, Córdoba, La Rioja, Salta, Tucumán and Jujuy provinces). All parts of this species have been used medicinally by indigenous people as a digestive, stimulant, diuretic, astringent, and antidepressant and for topical use as wound healer and skin antiseptic (Martínez \& Barboza, 2010).

Chemical compositions of essential oil of $S$. arei$\mathrm{ra}$ from aerial parts (leaves and flowers) collected from Mendiolaza, Córdoba, Argentina revealed that the chromatographic profile was predominantly composed by monoterpenes compounds $(66.4 \%)$; the main components were $\alpha$-pinene $(13.80 \%)$, limonene $(12.81 \%)$ and camphene $(12.62 \%)$ (Bigliani et al., 2012). Other chemical compositions of essential oils from aerial parts of $S$. arei$r a$ were reported by Scrivanti et al. (2003), Wannaz et al. (2003) and Murray et al. (2005). Extensive studies concerned with the chemical composition of EO isolated from S. molle have been reported (Marongiu et al., 2004; Hayouni et al., 2008; Atti dos Santos et al., 2009; Mendonça Rocha et al., 2012) showing the basic constituents $\alpha$-phellandrene, $\beta$-phellandrene, myrcene and $\alpha$-pinene. These essential oil compositions are different from Chilean species as Schinus ploygamus and Schinus longifolia (Mur-

e-mail: smoreno@leloir.org.ar

\#Both authors contributed equally to this work

*Present at the $5^{\text {th }}$ Central European Congress of the Life Sciences EUROBIOTECH 2013, Kraków, Poland

Abbreviations: EO, essential oils; MRSA, methicillin-resistant Staphylococcus aureus; MDR, multidrug-resistant bacteria; Py1F, Pinchayoc 1 fruits; Py1L, Pinchayoc 1 leaves; Tg2F, Tilcara 2 fruits; Tg2L, Tilcara 2 leaves 
ray et al., 2009). The chemical compositions of Schinus oils, are focused generally on fruits, however, correlation between their constituents and the biological action are issues that have not been totally investigated.

Previously, we reported the chemical composition of $\mathrm{EO}$ from fruits of $S$. areira at the same state of development which showed similar qualitative chemical profile, but containing different amounts of the main bioactive compounds (limonene, $\alpha$ - and $\beta$-phellandrene, sabinene and camphene) in relation to the geographic origin ( $\mathrm{Vi}$ turro et al,. 2010). The aim of the present study was to evaluate the antibacterial activity of $\mathrm{EO}$ isolated both from leaves and fruits of two specimens of $S$. areira growing in Jujuy, Argentina displaying different chemical profiles against the human pathogenic bacteria $S$. aureus susceptible as well as resistant to antibiotics.

\section{MATERIAL AND METHODS}

Plant material. Aerial parts (leaves and fruits) of $S$. areira L. were collected in May 2013 in Jujuy, Argentina from over ten-year-old trees. Sample $\mathrm{HN}^{\circ}$ 13-12 was collected from the specimen Pinchayoc (Py1) in Humahuaca region (altitude above $2900 \mathrm{~m}$ ). Sample $\mathrm{HN}^{\circ}$ 13-16 was collected from the specimen Tilcara $(\mathrm{Tg} 2)$ in Tilcara region (altitude above $2500 \mathrm{~m}$ ). The plant material was identified by Professor Gustavo Giberti (University of Buenos Aires, Argentina).Voucher specimens have been deposited in Herbarium of PRONOA-UNJu (Faculty of Engineering from National University of Jujuy, Argentina) and herbarium BAF (Buenos Aires Farmacobotánica, University of Buenos Aires, Argentina). The harvested materials were air-dried at room temperature $\left(20 \pm 2^{\circ} \mathrm{C}\right)$ for 1 week (fruits) and 3-5 days (leaves).

EO extraction. Oils were extracted from $200 \mathrm{~g}$ dried material (grinded fruits or leaves) by steam distillation for 2.5-3.5 h with a Clevenger trap. Py1 and Tg2 dried leaves yielded 0.49 and $0.52 \%$ (w/w on dry weight basis) of colorless essential oil, respectively, while the steam distillation of Py1 and Tg2 grinded fruits yielded 4.16 and $3.32 \%$ (w/w on dry weight basis), respectively, of pale yellowish oils with a distinct smell.

The collected oil samples were dried $\left(\mathrm{Na}_{2} \mathrm{SO}_{4}\right)$ and stored at $4{ }^{\circ} \mathrm{C}$ until analysis by GC/MS and GC/FID.

Chemical characterization of EO. GC/MS analysis was carried out on a Hewlett Packard GC 6890/ MDS 5972 apparatus equipped with a HP-5 MS column $(30 \mathrm{~m} \times 0.25 \mathrm{~mm} ; 0.25 \mu \mathrm{m}$ film thicknesses $)$ and a $\mathrm{N}_{2}$ carrier gas flow of $0.7 \mathrm{~mL} / \mathrm{min}$. The oven temperature program was $60^{\circ} \mathrm{C}(5 \mathrm{~min}), 60-230^{\circ} \mathrm{C}\left(6^{\circ} \mathrm{C} /\right.$ min). The temperature of the transfer line $\left(300^{\circ} \mathrm{C}\right)$ and of the injector $\left(250^{\circ} \mathrm{C}\right)$ was held constant during analysis. GC/FID analysis was carried out on a Konik KNK $3000 \mathrm{G}$ with a unique injector connected by a flow splitter $Y$ shaped to two columns: a) Innowax 20 $\mathrm{M}$ and b) HP5, both $60 \mathrm{~m} \times 0.25 \mathrm{~mm}$ with 0.250 .25 $\mu \mathrm{m}$ film thickness. Carrier gas $\mathrm{H} 2$; flow rate $1.2 \mathrm{~mL} /$ min. The oven temperature program was the same as above. Injector and both FID temps were set at $25^{\circ} \mathrm{C}$ and $300^{\circ} \mathrm{C}$ respectively. The components of the EO were identified by comparison of their Retention indices (RI) and mass spectra with those from literature data (Adams, 2007; Jennings, 1980), those recorded in the MS library (NBS 75K, NIST98), and those of a spectra library built up from pure substances and components of known oils. The RI was determined relative to a series of $n$-alkanes $\left(\mathrm{C}_{7}-\mathrm{C}_{24}\right)$. The quantification of each compound was performed on the basis of their GC/FID peak areas without the use of response factor corrections.

Antibacterial activity. The in vitro antibacterial activity of the $S$. areira oils was evaluated against the human pathogenic bacteria S. aureus ATCC 25923 and a nosocomial multidrug-resistant strain of S. aureus (MRSA, 1977 strain). MRSA 1977 (mec+, nuc+) was isolated from a pediatric patient in the Pediatric Hospital S.A.M.I.C. "Prof. Dr. Juan P. Garrahan" and identified by standard methods according to the recommendations of the Manual of Clinical Microbiology (Versalovic et al. 2010). The resistance to antibiotics (oxacyllin, rifampicin, erythromycin, clindamycin and ciprofloxacin) was assessed according to the clinical and laboratory Standards Institute (CLSI) guidelines (CLSI 2012).

The overnight cultures were standardised by dilution with sterile Mueller-Hinton (MH) broth (Difco, MD, USA) to an absorbance of 0.07-0.1 at $625 \mathrm{~nm}$ according to Ojeda et al. (2013). The antibacterial activity of the EO was estimated by the microplate bioassay with slight modifications (CLSI, 2006). Dilutions in MH medium containing $0.5 \%$ Tween 80 were prepared from an $80 \%$ (v/v) EO in ethanol, as reported (González et al., 2003). Each oil $(3-50 \mu \mathrm{L} / \mathrm{mL}, 200 \mathrm{uL}$ per well) was incubated in 96-well flat bottom microplates together with each bacterial strain. The microplate was aseptically sealed, and incubated at $37^{\circ} \mathrm{C}$ for $16-24 \mathrm{~h}$ under constant shaking $(100 \mathrm{rpm})$. All experiments were performed in triplicate. The antibacterial activity was expressed as percentage of bacterial growth inhibition: \% inhibition $100 \times$ (Ab control- Ab Sample)/Ab Control where Ab Control is the absorbance of bacteria cultured alone. The minimum inhibitory and minimum bactericidal concentrations (MIC and MBC) were determined by a microplate-based assay. The MIC was defined as the lowest concentration of the oil that was able to inhibit the visible bacterial growth after $24 \mathrm{~h}$ incubation at $37^{\circ} \mathrm{C}$. The $\mathrm{MBC}$ was determined from the well of microplate with no visible bacterial growth. The viable colony forming unit CFU/ $\mathrm{mL}$ was estimated employing Trypticase soy broth (TSB) (Merck, Darmstadt, Germany) agar plates incubated at $37^{\circ} \mathrm{C}$ (Aguilar et al., 2012).

\section{RESULTS AND DISCUSSION}

\section{Chemical composition of the EO of S. areira by GC-MS}

Leaves and fruits of two specimens of $S$. areira (Py1; and Tg2) growing in Jujuy were collected and the chemical characterizations of their EO were performed. Table 1 shows the EO composition (\% total peak area) of leaves and fruits of $S$. areira by GC/FID-MS. Forty-five compounds representing $77-98 \%$ of the total EO were identified. Results showed that the composition of the oils from fruits and leaves for the same specimen was different. The major components vary in a wide range: limonene (2.5 to $35.7 \%$ ), myrcene (1.7 to $38.7 \%$ ), $\alpha$-phellandrene $(1.2$ to $30.9 \%)$, $\beta$-phellandrene $(1.8$ to $15 \%)$, sabinene (4.1 to $10.9 \%$ ) and camphene ( 0.1 to $4.1 \%)$. It is well known that the content of the EO from aromatic plants depends on several factors such as the geographical origin, the part of the plant from which the oil was obtained and the genetic background of the plant from which the oil was taken.

In an earlier poblational study, the analyzed EO from fruits of individual trees of the Humahuaca region (Jujuy, Argentina) could be grouped in clusters according to their chemical composition (Viturro et al., 2006). 
Table 1. Chemical composition of EO expressed as percentages obtained by distillation of leaves (L) and fruits (F) of S. areira from Py1 and Tg2 specimen

\begin{tabular}{|c|c|c|c|c|c|}
\hline \multirow{2}{*}{ Compoundc } & \multirow{2}{*}{$\mathrm{Rl}^{\mathrm{b}}$} & \multicolumn{4}{|c|}{ Content [\%] ${ }^{\mathrm{a}}$} \\
\hline & & Py1F & Py1L & $\operatorname{Tg} 2 \mathrm{~F}$ & $\mathrm{Tg} 2 \mathrm{~L}$ \\
\hline Tricyclene & 926 & $\operatorname{tr}$ & 0.7 & $\operatorname{tr}$ & 0.1 \\
\hline a-Thujene & 931 & 0.2 & 0.2 & 0.2 & 0.3 \\
\hline a-Pinene & 939 & 1.4 & 2.6 & 2.3 & 3.0 \\
\hline Camphene & 954 & 0.2 & 4.1 & 0.1 & 0.9 \\
\hline Sabinene & 977 & 8.0 & 10.9 & 4.1 & 6.9 \\
\hline$\beta$-pinene & 980 & 0.2 & 1.7 & 0.2 & 0.5 \\
\hline Myrcene & 992 & 13.3 & 1.7 & 38.7 & 3.3 \\
\hline a-Phellandrene & 1005 & 1.2 & 6.4 & 30.9 & 24.7 \\
\hline a-Terpinene & 1019 & $\operatorname{tr}$ & 0.3 & 0.1 & 0.5 \\
\hline p-Cymene & 1029 & 5.5 & 0.8 & 0.9 & 4.7 \\
\hline Limonene & 1035 & 35.7 & 15.5 & 2.5 & 5.8 \\
\hline$\beta$-Phellandrene & 1036 & 2.4 & 1.8 & 15.0 & 13.0 \\
\hline cis- $\beta$-Ocimene & 1043 & $\operatorname{tr}$ & 0.1 & $\operatorname{tr}$ & $\operatorname{tr}$ \\
\hline trans- $\beta$-Ocimene & 1054 & $\operatorname{tr}$ & $\operatorname{tr}$ & $\operatorname{tr}$ & 0.1 \\
\hline Y-Terpinene & 1063 & $\operatorname{tr}$ & 0.5 & 0.2 & 0.8 \\
\hline Terpinolene & 1090 & $\operatorname{tr}$ & 0.2 & 0.1 & 0.3 \\
\hline Linalool & 1098 & 0.4 & $\operatorname{tr}$ & $\operatorname{tr}$ & 0.1 \\
\hline Methyl octanoate & 1129 & 1.0 & 0.1 & 0.7 & - \\
\hline Terpinen-4-ol & 1186 & $\operatorname{tr}$ & $\operatorname{tr}$ & $\operatorname{tr}$ & $\operatorname{tr}$ \\
\hline a-Terpineol & 1188 & 0.7 & 0.1 & $\operatorname{tr}$ & 0.1 \\
\hline Cryptone & 1192 & 0.3 & $\operatorname{tr}$ & $\operatorname{tr}$ & $\operatorname{tr}$ \\
\hline Bornyl acetate & 1288 & $\operatorname{tr}$ & 0.7 & $\operatorname{tr}$ & 0.1 \\
\hline para-Cymen-7-ol- & 1292 & 0.3 & $\operatorname{tr}$ & $\operatorname{tr}$ & $\operatorname{tr}$ \\
\hline$\delta$-Elemene & 1340 & 1.6 & 0.2 & $\operatorname{tr}$ & 0.2 \\
\hline$\beta$-Elemene & 1393 & 1.2 & 0.7 & 0.1 & 0.8 \\
\hline$\beta$-Caryophyllene & 1419 & 0.9 & 0.8 & 0.2 & 1.1 \\
\hline a-Humulene & 1455 & 0.3 & 0.8 & 0.1 & 0.9 \\
\hline Germacrene-D & 1480 & 0.2 & 0.3 & 1.0 & 0.4 \\
\hline Y-Muurolene & 1482 & $\operatorname{tr}$ & 0.3 & $\operatorname{tr}$ & 0.4 \\
\hline Bicyclogermacrene & 1500 & 0.5 & 12.3 & $\operatorname{tr}$ & 3.0 \\
\hline a-Muurolene & 1501 & 0.7 & - & 0.1 & 1.0 \\
\hline$\beta$-Bisabolene & 1506 & $\operatorname{tr}$ & 0.5 & 0.1 & 0.4 \\
\hline y-Cadinene & 1516 & 0.6 & 0.9 & 0.1 & 1.0 \\
\hline Bourbonanol-endo-1 & 1521 & $\operatorname{tr}$ & 0.3 & - & - \\
\hline$\delta$-Cadinene & 1526 & 1.2 & 3.0 & 0.4 & 4.3 \\
\hline Elemol & 1552 & 0.2 & 0.9 & - & 0.2 \\
\hline Germacrene-D-4-ol & 1578 & 4.1 & 3.9 & 0.2 & 1.8 \\
\hline$\beta$-Oplopenone & 1608 & $\operatorname{tr}$ & $\operatorname{tr}$ & $\operatorname{tr}$ & $\operatorname{tr}$ \\
\hline Cubenol-1,10-di epi & 1624 & $\operatorname{tr}$ & 0.2 & $\operatorname{tr}$ & $\operatorname{tr}$ \\
\hline Cubenol-1-epi & 1631 & $\operatorname{tr}$ & $\operatorname{tr}$ & $\operatorname{tr}$ & 0.3 \\
\hline$\gamma$-Eudesmol & 1634 & $\operatorname{tr}$ & 0.1 & $\operatorname{tr}$ & - \\
\hline epi-a-Muurolol & 1644 & 1.2 & 1.4 & 0.1 & 1.7 \\
\hline$\beta$-Eudesmol & 1653 & 0.3 & 0.3 & - & 0.1 \\
\hline a-Eudesmol & 1655 & 1.2 & 1.9 & 0.2 & 2.4 \\
\hline a-Cadinol & 1658 & $\operatorname{tr}$ & $\operatorname{tr}$ & $\operatorname{tr}$ & $\operatorname{tr}$ \\
\hline
\end{tabular}

aPercentage peak area of EO components. ${ }^{b}$ Experimental retention indices on HP5 MS capillary column in reference to $C_{7}-C_{24} n$-alkanes; the compounds are listed in order of elution. cAll compounds were identified by comparison of their RI and mass spectra with literature data, the MS library (NBS 75K, NIST98), and a spectra library built up from pure substances and components of known oils. -not detected; tr, traces $(<0.1 \%)$ 

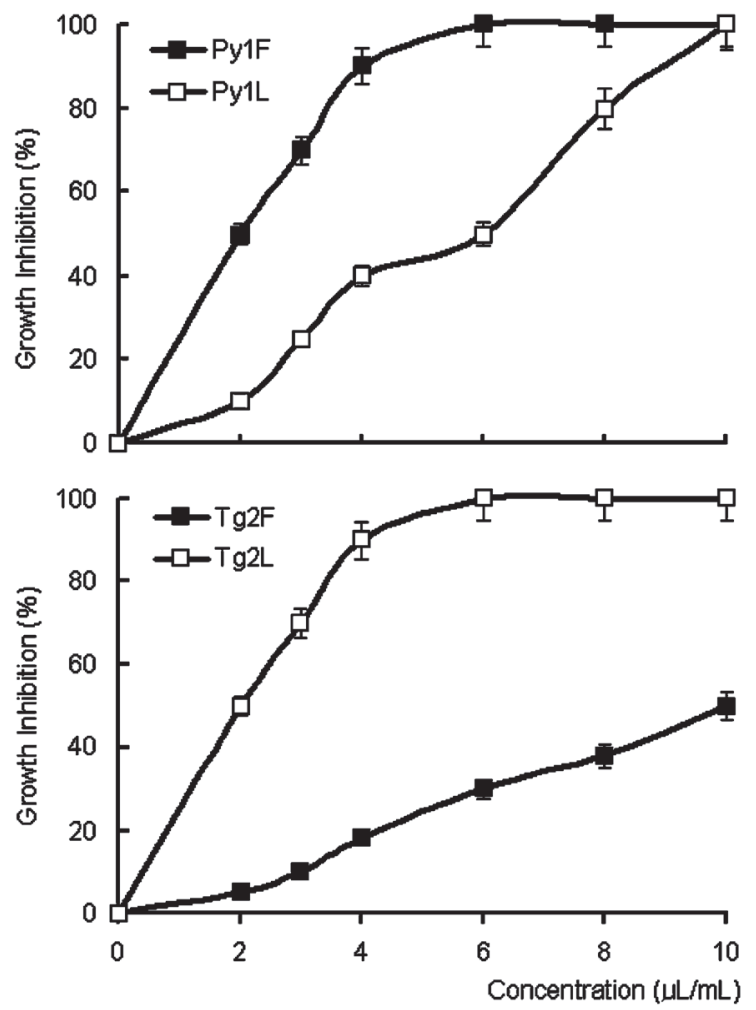

Figure 1. Antibacterial activity of $S$. areira EO from Py1 specimen (A) and Tg2 specimen (B) against S. aureus ATCC 25923. EO from fruits (filled squares) or leaves (empty squares).

Moreover, these chemical profiles were detected in these Argentinean S. areira specimens for over 7 years; therefore they are mainly determined by the genotype of the plants.

Wannaz et al. (2003) studied the chemical composition of volatile compounds sampling in Mendoza city, Argentina and reported that limonene and $\alpha$-phellandrene show the higher percentages while the greatest variability belonged to sabinene, myrcene and tricyclene. A different chemical composition was obtained for other EO of plants collected from Mendiolaza, Córdoba, Argentina, finding as the main components: $\alpha$-pinene $(13.80 \%)$, limonene $(12.81 \%)$ and camphene $(12.62 \%)$ (Bigliani et al., 2012).

It is well known that whole EO tend to vary in their exact composition due to factors such as seasonal variation, climate, humidity, sun exposure and even the oilextraction method (Edris, 2007). Therefore, due to the large chemical variability observed in the $\mathrm{EO}$ of $S$. areira, it is likely to find different antibacterial efficiencies depending on the chemical composition of the oils.

Table 2. The minimal inhibitory concentration (MIC) and minimal bactericide concentration (MBC) of EO from the fruits (F) and leaves (L) of Py1 and Tg2 specimens against S. aureus ATCC 25923

\begin{tabular}{lll}
\hline Treatment & $\begin{array}{l}\mathrm{MIC} \\
(\mu \mathrm{L} / \mathrm{mL})\end{array}$ & MBC \\
\hline EO Py1F & 6 & 20 \\
\hline EO Py1L & 10 & 30 \\
\hline EO Tg2F & $30^{*}$ & n.a. \\
\hline EO Tg2L & 6 & 30 \\
\hline
\end{tabular}

${ }^{*}$ Corresponded to a growth inhibition of $70 \%$. n.a., not active

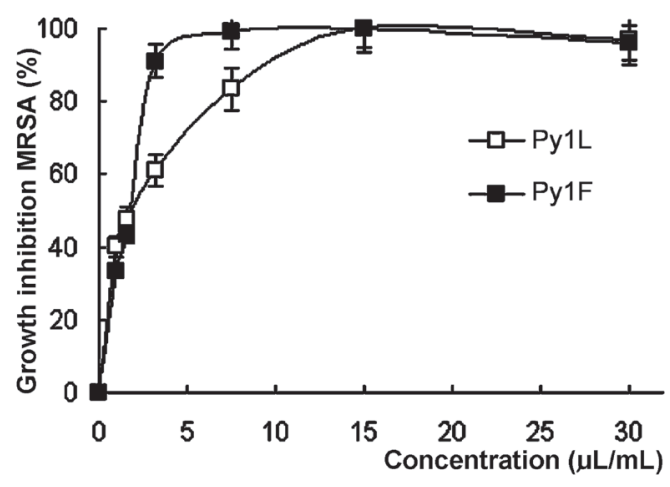

Figure 2. Antibacterial activity of $S$. areira EO from Py1 from fruits (filled squares) or leaves (empty squares) against MRSA evaluated by the microplate bioassay.

Antibacterial activity of fruits and leaves of four EO of S. areira (Py1 and Tg2) against S. aureus ATCC 25923

First, the antibacterial activity of fruits and leaves of both EO of $S$. areira (Py1 and Tg2) was evaluated against a susceptible to antibiotics $S$. aureus strain by the microplate bioassay testing different amounts of them. Figure 1 shows the antibacterial activity expressed as a percentage of bacterial growth inhibition and the results displayed dose dependent curves for the four oils assayed. The oil of Py1 fruits had higher antibacterial activity than the EO of leaves, although both were able to inhibit the bacterial growth in a $100 \%$ (Fig. 1A). A different behavior was observed when the oils of fruits and leaves obtained from $\mathrm{Tg} 2$ specimen were assayed. In this case, the EO obtained from the fruits exhibited a lower efficacy than the oils obtained from the leaves, since it was unable to induce a total inhibition of the growth of S. aureus ATCC 25923 (Fig. 1B). Table 2 shows the MICs values of the EO of fruits and leaves of the specimen Py1 against the susceptible strain of $S$. aureus $(6 \mu \mathrm{L} / \mathrm{mL}$ and $10 \mu \mathrm{L} / \mathrm{mL}$, respectively), while the oil of the leaves of $\mathrm{Tg} 2$ was $6 \mu \mathrm{L} / \mathrm{mL}$. Later, we examined whether bacteriostatic or bactericide actions were performed by the EO of $S$. areira. Bactericide effects were obtained after treatment with $3 \mathrm{X} 5 \mathrm{X}$ MIC values of leaves of both specimens, although the EO of fruits of Py1 exhibited the higher bactericide concentrations $(20 \mu \mathrm{L} / \mathrm{mL}$ ) (Table 2). Again, Tg2 specimen oil showed the lowest antibacterial potency because it showed no bactericidal effects assaying up to $40 \mu \mathrm{L} / \mathrm{mL}$.

Given the observed difference in the antibacterial efficacy of the four oils from $S$ areira studied, we hypoth-

Table 3. Colony forming unit (CFU) recovered after treatment with S. areira EO isolated from leaves (L) and fruits (F) of $\mathrm{Py} 1$ and Tg2 specimens against MRSA 1977

Treatment Mean bacterial count (CFU \pm S.D.)

\begin{tabular}{ll}
\hline Inoculum, $0 \mathrm{~h}$ & $5.5 \times 10^{5} \pm 1.5 \times 10^{4}$ \\
\hline Bacterial culture, $24 \mathrm{~h}$ & $2.3 \times 10^{7} \pm 0.5 \times 10^{6}$ \\
\hline $20 \mu \mathrm{L} / \mathrm{mL}$ EO Py1F & 0 \\
$30 \mu \mathrm{L} / \mathrm{mL}$ EO Py1L & $2.3 \times 10^{2}$ \\
$20 \mu \mathrm{L} / \mathrm{mL}$ EO Tg2F & n.a. \\
$30 \mu \mathrm{L} / \mathrm{mL}$ EO Tg2L & 0 \\
\hline
\end{tabular}

n.a., not active 
esized that the antibacterial activity of these EO could, in part, be to their major components (limonene and $\alpha$-phellandrene). The oil of Py1 fruits containing higher amount of limonene $(35.5 \%)$ was more potent than Py1L oil bearing half of the content $(15.5 \%)$ of this active compound. Limonene has been demonstrated to have bacteriostatic activity against several microorganisms and against Staphylococcus aureus CCTCC AB91053 (Bakkali et al., 2008; Donsì et al., 2011; Dai et al., 2013). It can also be speculated that $\mathrm{Tg} 2 \mathrm{~F}$ would have a lower antibacterial activity than $\mathrm{Tg} 2 \mathrm{~L}$, possibly due to the fact that it contained a lower amount of limonene. On the other hand, the antimicrobial efficacy of $\mathrm{Tg} 2$ specimens may be also attributed to $\alpha$-phellandrene. The antimicrobial activities of $\alpha$-phellandrene have been also reported (Simic et al., 2002).

\section{Antibacterial activity of the EO of S. areira against MRSA}

MRSA infections are a major public health problem producing a large number of deaths every year worldwide (NNIS, 2004). This important nosocomial and community-acquired pathogen has developed resistance to various antibiotics ( $\beta$-lactams, quinolones, and aminoglycosides) (Chen et al., 2010). For this reason we evaluated the EO isolated from $S$. areira against a nosocomial MDR strain of $S$. aureus isolated from a Pediatric Hospital in Argentina. We observed a dose-response curve for the antibacterial activity of EO from fruits and leaves of Py1 specimen (sample 13-12) against MRSA (Fig. 2). Results obtained also showed that the $100 \%$ of growth inhibition (MICs value) of the EO from fruits and leaves 13-12 were $3.2 \mu \mathrm{L} / \mathrm{mL}$ and $15 \mu \mathrm{L} / \mathrm{mL}$, respectively. Importantly, both leaves and fruits oils exhibited bactericidal action after incubation for $24 \mathrm{~h}$ with $20 \mu \mathrm{L} / \mathrm{mL}$ and $40 \mu \mathrm{L} / \mathrm{mL}$, respectively (Table 3 ). In addition, EO from fruits of $\mathrm{Tg} 2$ (sample 13-16) is inactive against SAMR, while that of the leaves are active assessing $30 \mu \mathrm{L} / \mathrm{mL}$.

It is difficult to attribute the antibacterial effect of the oils to particular compounds, because they contain a mixture of different chemical compounds where synergy and antagonism phenomenon may occur. However, taking into account the results presented herein, it could be inferred that the antibacterial effectiveness of $S$. areira essential oils depend on an adequate number and content of key bioactive/s compound/s. In fact, the antibacterial action of the $S$. areira oils against $S$. aureus strains is probably due to the content of limonene. However, it cannot be ruled out that the antibacterial action of the oils from Tg2 specimens can be the result of the synergistic effects of $\alpha$-phellandrene and limonene. Further studies are needed to address this possibility.

The mechanism of action of this class of compounds has not been completely elucidated to date; however, the antimicrobial activity of the essential oils of herbs and spices or their components could be the result of disruption of bacterial membrane integrity or disturbance of several enzymatic cell systems, including energy production and synthesis of structural components (Burt, 2004).

\section{CONCLUSIONS}

The essential oils from many plants are of great interest to food, cosmetic, and pharmaceutical industries because of their possible use as natural additives to replace synthetic antimicrobial agents. This is the first study showing the effective killing activity of susceptible and multidrug-resistant $S$. aureus strains of the EO isolated from fruits and leaves of $S$. areira. As the inherent activity of these oils may be related to their chemical composition and the proportions of the main components, our finding revealed that the oil from leaves and fruits of $S$. areira may be a new potential source of natural antimicrobial agent. In particular, results point out the use of the $S$. areira oils against Staphylococcal infections. However, further studies need to be conducted to obtain more information on the safety and toxicity of these oils.

\section{Acknowledgements}

National Agency of Scientific and Technological Promotion, Argentina: Grant PICTO 00150, LAnaRT (Jujuy, Argentina) and the National Council for Scientific and Technological Research (CONICET), Argentina.

\section{REFERENCES}

Adams RP (2007) In: Identification of essential oil components by gas chromatography/Mass Spectroscopy, 4th edition, pp 804. Allured Publishing Corp, Carol Stream, Illinois, USA.

Aguilar MI, Piñón Y, Mejía A, Díaz-Ruiz G, Sánchez-Nieto S, RiveroCruz JF (2012). Ethnobotanical survey and antibacterial activity of plants of the Mexican altiplane used for the treatment of oral cavity infections. Planta Med 78: PI437.

Atti dos Santos AC, Rossato M, Agostini F, Atti Serafini L, dos Santos PL, Molon R, Dellacassa E, Moyna P (2009) Chemical composition of the essential oils from leaves and fruits of Schinus molle L. and Schinus terebinthifolius Raddi from Southern Brazil. J Ess oil-Bearing Plants 12: 16-25.

Bakkali F, Averbeck S, Averbeck D, Idaomar M (2008) Biological effects of essential oils-a review. Food Chem Toxicol 46: 446-475.

Bigliani MC, Rossetti V, Grondona E, Lo Presti S, Paglini PM, Rivero V, Zunino MP, Ponce AA (2012) Chemical compositions and properties of Schinus areira L. essential oil on airway inflammation and cardiovascular system of mice and rabbits. Food Chem Toxicol 50: 2282-2288.

Burt S (2004) Essential oils: their antibacterial properties and potential applications in food, Review. Int Food Microbiol 94: 223-253.

Dai J, Zhu L, Yang L, Qiu J (2013) Chemical composition, antioxidant and antimicrobial activities of essential oil from Wedelia prostrata. EXCLI Journal 12: 479-490.

Cáceres Guido PA, Ojeda Sana AM, Blanco A, Lopardo H, Macchi A, van Baren CM, Dellorso M, Moreno S (2012) Bioactive compounds from Rosmarinus officinalis against multidrug-resistant clinical strains of Staphylococcus aureus: in vitro activity. Pediatric Res 72: 109.

Donsì F, Annunziata M, Sessa M, Ferrari G (2011) Nanoencapsulation of essential oils to enhance their antimicrobial activity in foods. LWT - Food Sci Technol 44: 1908-1914.

Chen SY, Wang JT, Chen TH, Lai MS, Chie WC, Chien KL, Hsueh PR, Wang JL, Chang SC (2010) Impact of traditional hospital strain of Methicillin-Resistant Staphylococcus aureus (MRSA) and community strain of MRSA on mortality in patients with community-onset $S$. aureus bacteremia. Medicine 89: 285-294.

CLSI (2006) Clinical and Laboratory Standards Institute. Methods for dilution antimicrobial susceptibility test for bacteria that grow aerobically; approved standard (7 ed, approved standard M7-A7). Wayne, PA, USA.

CLSI (2012) Clinical and Laboratory Standards Institute. Performance standards for antimicrobial susceptibility testing (M100-S22, 32, 3). Wayne, PA, USA.

Cowan MM (1999) Plant products as antimicrobial agents. Clin Microbiol Rev 12: 564-582.

Dorman HJD, Deans SG (2000) Antimicrobial agents from plants: Antibacterial activity of plant volatile oils. J Applied Microbiol 88: 308-316.

Edris AE (2007) Pharmaceutical and therapeutic potentials of essential oils and their individual volatile constituents: a review. Phytother Res 21: 308-323.

González CA, Molina AC, Viturro CI (2003) Screening de Mínima Concentración Inhibitoria de aceites esenciales de especies aromáticas de Jujuy. In: Proceedings X Jornadas Argentinas de Microbiología. Santa Fe, Argentina.

Grundmann H, Aires-de-Sousa M, Boyce J, Tiemersma E (2006) Emergence and resurgence of methicillin-resistant Staphylococcus aureus as a public-health threat. The Lancet 368: 874-885.

Hayouni EA, Chraief I, Abedrabba M, Bouix M, Leveau JY, Hammami M, Hamdi M (2008) Tunisian Salvia officinalis L. and Schinus molle L. essential oils: their chemical compositions and their preservative effects against Salmonella inoculated in minced beef meat. Int $J$ Food Microbiol 125: 242-251. 
Jennings W, Shibamoto S (1980) In: Qualitative analysis of flavor fragrance volatiles by gas capillary chromatography, Academic Press, New York, USA.

Kon KV, Rai MK (2012) Plant essential oils and their constituents in coping with multidrug-resistant bacteria. Expert Rev Anti Infect Ther 10: $775-790$.

Langeveld WT, Veldhuizen EJA, Burt SA (2014) Synergy between essential oil components and antibiotics: a review. Crit Rev Microbiol 40: 76-94.

Marongiu B, Porcedda APS, Casu R, Pierucci P (2004) Chemical composition of the oil and supercritical CO2 extract of Schinus molle L. Flav Frag J 19: 554-558.

Martínez GJ, Barboza GE (2010) Natural pharmacopoeia used in traditional Toba medicine for the treatment of parasitosis and skin disorders (Central Chaco, Argentina). J Ethnopharmacol 132: 86-100.

Mendonça Rocha PM, Rodilla JM, Díez D, Elder H, Guala MS, Silva LA Pombo (2012) Synergistic antibacterial activity of the essential oil of Aguaribay (Schinus molle L.). Molecules 17: 12023-12036.

Molina-Salinas GM, Pérez-López A, Becerril-Montes P, Salazar-Aranda R, Said-Fernández S, de Torres NW (2007) Evaluation of the flora of northern Mexico for in vitro antimicrobial and antituberculosis activity. J Ethnopharmacol 109: 435-441.

Muñoz JD (2000) Flora Fanerogámica Argentina. Fasc. 65:153. Anacardiaceae. CONICET Ed, pp 11-26. Buenos Aires, Argentina.

Murray AP, Frontera MA, Tomas MA, Mulet MC (2005) Gas Chromatography-Mass Spectrometry Study of the Essential oils of Schinus longifolia (Lindl.) Speg. Schinus fasciculata (Griseb.) IM Johnst and Schinus areira L. Z. Naturforsch. 60: 25-29.

Murray AP, Gurovic MS, Rodríguez SA, Murray MG, Ferrero AA (2009) Acetylcholinesterase inhibition and antioxidant activity of es- sential oils from Schinus areira L. and Schinus longifolia (Lindl.) Speg. Nat Prod Commun 4: 873-876.

National Nosocomial Infections Surveillance (2004) National Nosocomial Infections Surveillance (NNIS) System Report, data summary from January 1992 through June 2004, issued October 2004. Am J Infect Control 32: 470-485.

Ojeda-Sana AM, van Baren CM, Elechosa MA, Juárez MA y Moreno S (2013). New insights into antibacterial and antioxidant activities of rosemary essential oils and their main components. Food Control 31: 189-195.

Simic N, Palic R, Vajs V, Milosavljevic S, Djokovic D (2002) Composition and antibacterial activity of Achillea asplenifolia essential oil. $J$ Essent Oil Res 14: 76-78.

Versalovic J, Carroll KC, Funke G, Jorgensen JH, Landry ML, Warnock DW, ed. (2011) Manual of Clinical Microbiology, 10th ed, ASM Press, Washington DC, USA.

Viturro C, Corro M, Molina A, Heit C, Villa W, Bandoni A, Elder H, Dellacassa E (2006) Estudios exploratorios de variabilidad de composición para la normalización de un producto regional. In Investigaciones en Facultades de Ingeniería del NOA 2: 309-316.

Viturro C, Bandoni A, Dellacassa E, Serafini LA, Elder H (2010) Cap. 10: Problemática Schinus en Latinoamérica. In Proyecto CYTED IV.20. Dellacassa, ed, pp 205-280. Edit. Universitaria da PUCRS. Porto alegre, Brasil.

Wannaz ED, Zygadlo JA, Pignata ML (2003) Air pollutants effect on monoterpenes composition and foliar chemical parameters in Schinus areira L. Sci Total Environ 305: 177-193. 